International Journal of Engineering \& Technology, $7(3.15)(2018) 324-328$
International Journal of Engineering \& Technology
SPC
Website: www.sciencepubco.com/index.php/IJET
Research paper

\title{
Monitoring Concept of the Information Support System Organization of the Anti-Crisis Management of the Regional Agro-Industrial Complex
}

\author{
Edward Kitovich Tkhakushinov, Emma Aslanovna Khachemizova \\ Maikop State Technological University, Russia, 385000, Republic of Adygea, Maikop, Pervomayskaya St. 191
}

\begin{abstract}
The article is devoted to the problems of ensuring efficient management of the agro-industrial complex (AIC) in the region and a systematic analysis of economic processes in crisis situations. The authors discuss the anti-crisis management system involving the formulation of necessary solutions aimed at supporting the subjects of the AIC in economic equilibrium, based on having an effective monitoring mechanism. This management system ensures a rapid response to sudden changes in economic factors and offers a set of alternative solutions to determine the strategy and tactics of the AIC development.

The monitoring concept of anti-crisis management is justified, based on the organization of a powerful monitoring mechanism, enabling timely, necessary and sufficient analysis of the processes and patterns of managing socio-economic processes. At the same time, a special role is given to interaction between design and expert assessments of the factors of crisis situations, making it possible to characterize the degree of influence of a crisis change in the conditions of the external environment on the economy of the subjects and the whole AIC in general.
\end{abstract}

Keywords. Management, organization, system, region, agro-industrial complex, economics, development, efficiency, production.

\section{Introduction}

The notion "management" is defined by many domestic and foreign experts. However, all of them are based on the definition of A. Fayol, who believes that to manage means: "to predict and plan, organize, manage, coordinate and plan" [1].

Other authors assume essentially the same set of functions, but in different combination and quantity. It is considered as a series of continuous interrelated actions, which are represented in the form of management functions [2].

This approach to the study of control is called the process approach, where process management is considered as a sum of all these functions [3].

There are other approaches to management complex, integration, marketing, dynamic, functional, behavioral, etc. It is possible to note that all of these approaches, including the process approach, are considered in the framework of the system approach. In this case, any system (object) is considered as a set of interrelated elements, forming certain integrity, unity [4].

The system control is designed to provide focused managerial performance under variable conditions. This can be achieved through an appropriate system. An organization should be understood as a structure built on the basis of the relevant principles and the way of its functioning.

\section{The Main Part}

In the economic system, which includes the agro-industrial complex (AIC), the choice and formation of both its structure and the way of functioning are the management tasks that ensure the dy- namics of development of agribusiness entities [5].

In the system formation, its controlled elements are combined into a manageable part of the $\mathrm{CO}$ (control object). A management system (MS) is a set of controls that interact with the $\mathrm{CO}$ through many data connections (Fig.1). 


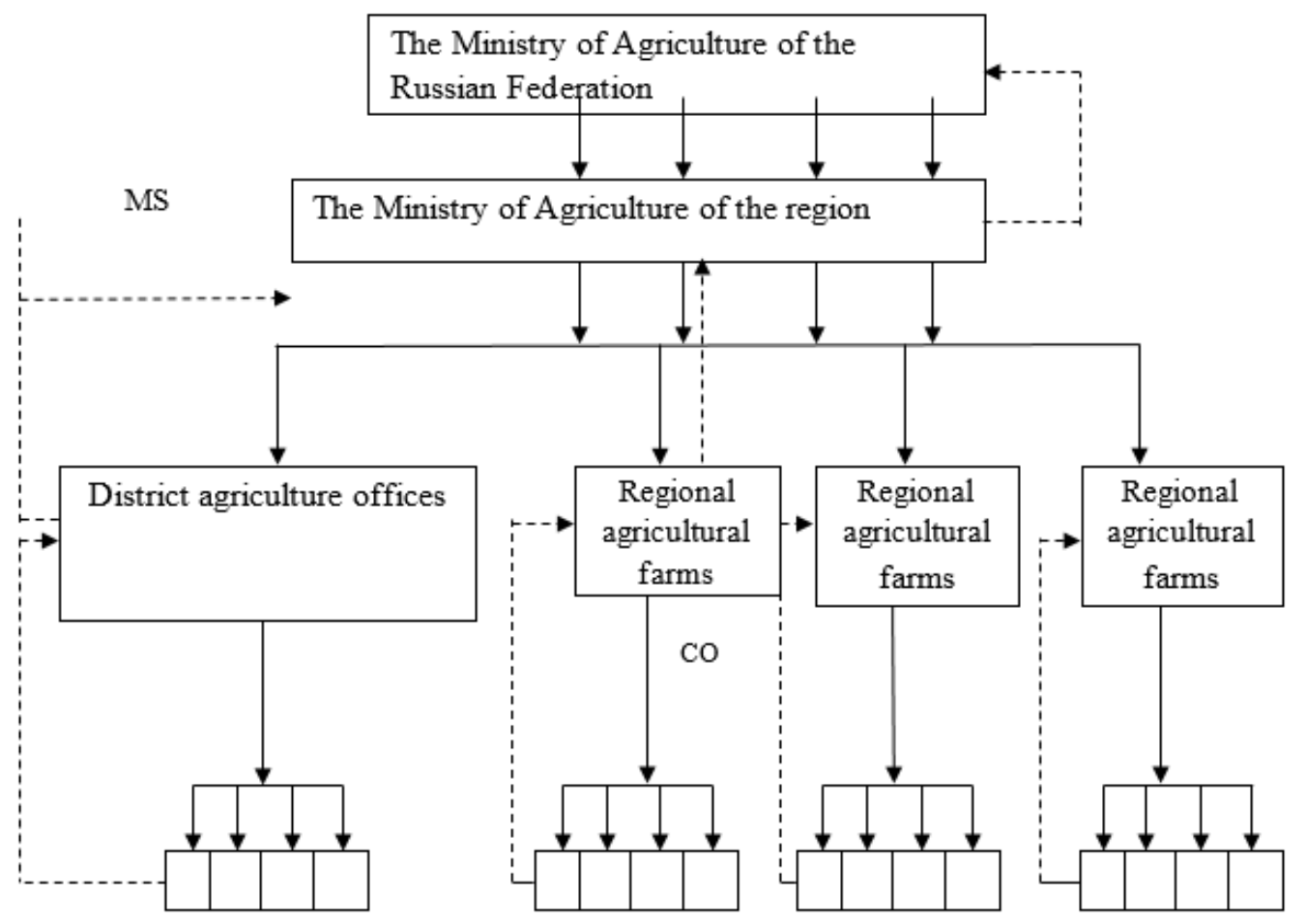

Agribusiness entities

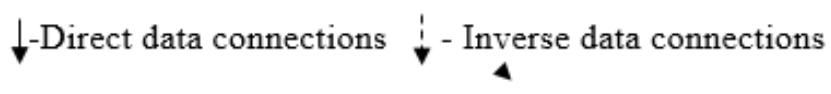

Fig.1:. AIC management system.

The management process can be represented as the implementation of two management stages - a development program, defining the required behavior of a control object (planning) and operational management. In the first approximation, this refers to the functions of planning and regulation.

In relation to the management of the agricultural sector, the planning function undertaken by the MS involves the development of a strategy of agricultural development, has the characteristic features of the process of forecasting the set of agribusiness entities in the so-called "scenarios" that define in general terms the options for economic development [6]. In modern conditions, as a rule, forecasting deals with economic situations, characterized by different levels of inflation [7].

It should be noted that the model plan, with whatever degree of detail it is presented, can only cover the main factors that affect the behavior of the object. It reflects mainly a mathematical treatment of the relationships in idealized conditions, and limitations for a specific period of time - a year, five years, etc.

The goal of operational management is to develop solutions tailored to the variety of factors that occur in a real situation. Operational management is the process in which the time factor becomes predominant, that is, the efficiency of the solutions largely depends on the provision of time for their development and adoption [8].

A characteristic feature of strategic management is that it takes place under the conditions of partial or complete uncertainty and its main task is to find the most effective ways of development of the organization on the basis of the potential of the control object and the trends of environmental factors [9]. It identifies the processes and factors occurring in the development of the organization that should be managed, in contrast to the uncontrollable processes that occur according to their own laws. The definition of these managed processes refers to the process of anti-crisis development and management. In this sense, there are two possible reasons leading to the crisis in the development of the organization: "not defining of" managed processes, the management of unmanaged processes and attempts to control in the conditions of crisis in the absence of control mechanisms [10]. The last reason is very characteristic of the modern state system of regional agribusiness management.

Any management system essentially has to be anti-crisis. The recognition of the cyclical nature of development leads to the formation of provisions, to a certain extent, making up the characteristics of anti-crisis management:

- $\quad$ incoming state in the development of the organization lends itself to forecasting and management;

- $\quad$ crisis processes are partially managed;

- $\quad$ management in crisis conditions should be based on a mechanism combining different technologies and knowledge management; process management of the way out of the crisis is aimed at speeding up these processes and mitigating their effects.

Modern anti-crisis management of the economy cannot be imagined without the use of complex economic-mathematical modeling of various systems, including management systems (E). An economic-mathematical model will be effective only if it reflects the major features of the economic process without too much detail of the modeling process to identify the main regularities of the process and to provide opportunities for practical use of the models. Planning models are based on some mathematical interpretation of the relationships between the indicators [11]. They can be defined as stochastic models designed to explain the observed factors.

In most cases, the use of static models is based on the assumption that the managed object is in equilibrium. In operational management, the dominant importance belongs to the time factor and inertia, that is, the desired model of operational management is a dynamic inertial model.

The main objective of operational management can be formulated as a balance of the control object in the conditions of changes of uncontrollable factors.

The uncontrolled factors here include the environmental factors, the value of which cannot be changed using the management system. 
Management of a complex dynamic system, subjected to the impact of diverse and frequently changing external factors, is related to the need of attracting and processing huge amounts of information. Therefore, the structure of management is based on the hierarchical principle.

The operation of the management system as a whole is achieved by the coordination of management objectives of each element and their sets with the objectives for the system [12]. The hierarchy of the management system corresponds to a hierarchy of goals. Each hierarchical level carries out the planning function and operational management.

Currently, the AIC management system of the region is repre- sented by three hierarchical levels, each of which has its target orientation, as well as the content management functions (Fig.2).

As noted above, the function of operational management is carried out by each level of the control chart. The main purpose of the implementation of this function is the maintenance of actions of a control object in a dynamic equilibrium in accordance with the developed plans, standards, and patterns of behavior [13].

A quantitative characteristic, allowing assessing management efficiency, is the optimality criterion defined as a function of the input variables, parameters of the control object, and time [14].

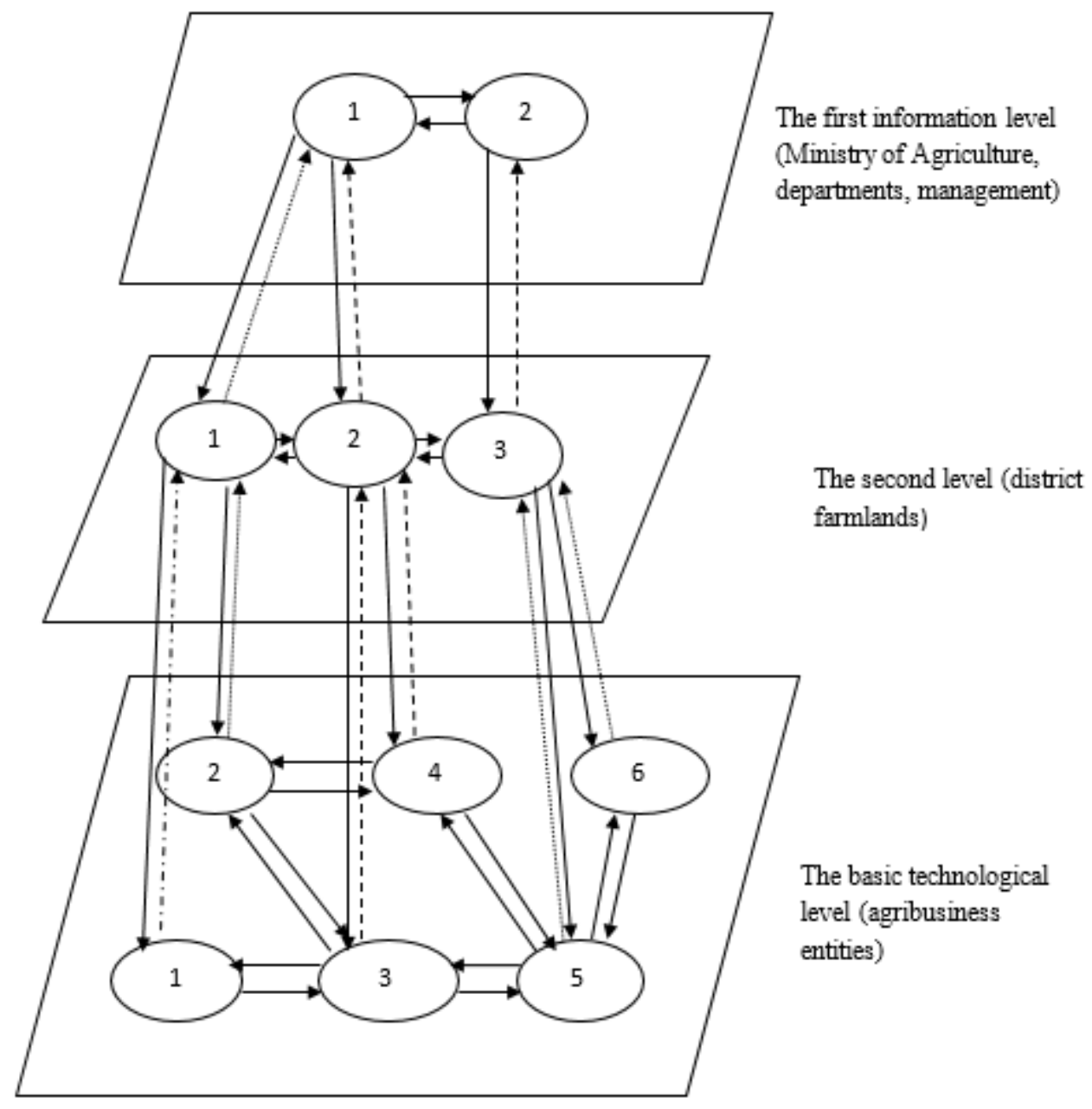

Fig.2:. AIC hierarchical management scheme

This function is called the objective function. The purpose of the operational management can also be defined as the maintenance of values of the objective function within the specified limits.

The current state of the economy is characterized by high uncertainty, rapid changes in the values of environmental factors [15].

Under the current management practice, control objects often do not have time to change their behavior in accordance with the current situation. To fill this gap is offered by the organization of anti-crisis management system as a subsystem of the general management system (Fig.3), which can be represented as linking the main phases of the management process. The aforesaid function of anti-crisis management must be performed at each hierarchical level. 


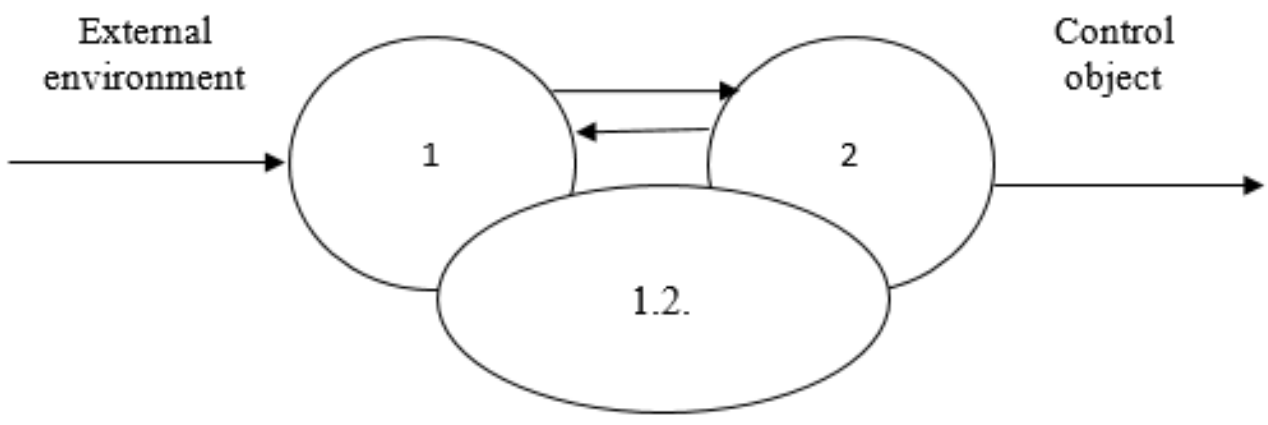

1- planning;

2- operational management;

\section{3- anti-crisis management.}

Fig.3:. General scheme of anti-crisis management

The formation of the anti-crisis management system of the agricultural sector aims at achieving the main goal - ensuring regulatory processes of the socio-economic system and keeping it in balance in terms of the changes of the factors of external and internal environment that could lead the control object to a crisis situation.

The formation of anti-crisis management system must provide for the implementation of certain principles [16].

The goal principle is that the functioning of the anti-crisis management system should be done on the basis of the program-target approach in technology development and implementation of management decisions. The control system should be focused not only on the spheres of agribusiness, types of activities, but also on the specificity and methodology of current tasks. It is the principle of targeting that makes it possible to define the priorities in the development of the control object, to concentrate resources on the most critical areas to ensure targeted implementation of management decisions.

Anti-crisis management system must be built in keeping with the principle of integration, that is, it must unite all levels of management and agribusiness in the region, and to be represented in all management functions by relevant elements. It involves the reconstruction of a single chain of management which in modern conditions, unfortunately, is often torn. The implementation of the principle of integration lies in the fact that the implemented decisions in relation to one element of the agribusiness system accordingly have an effect on the efficiency of the whole control object.

The most important principle of anti-crisis management system is the principle of continuity that must be implemented in a continuous process of collection, processing and analyzing of information, continuous adjustment of the data bank and the methods of analysis and diagnosis. The interruption of these processes means the loss of control of the current situation in the AIC, the environment, adequate evaluation of management decisions, and the choice of alternatives to prevent and mitigate crisis situations. A failure to observe this principle in the organization of the anticrisis management system can lead to the loss of meaning in its existence.

The formed anti-crisis management system should provide for the possibility to define and study different ways and means to achieve objectives taking into account the probabilistic character of changes in economic processes in the organizational system and external environment. In this way, the necessity of implementing the principle of alternativeness is set in motion. The implementation of the principle of alternativeness in the organization of an anti-crisis management system is related to the need for taking into account the time factor in management processes, the changing factors of the external and internal environment of the control object, binding of methods, models and techniques of decisionmaking to specific economic situation, goals, and objectives.

The most complete implementation of the above-mentioned principles of the system of anti-crisis management is possible when using monitoring concepts of the organization of the anti-crisis management system of agribusiness of the region.

\section{Conclusion}

The monitoring concept of the organization of an anti-crisis management system involves the use in its base of a system mechanism, making it possible to solve complex management tasks on agribusiness management in crisis situations and stabilize its operation. The main, most aggregated subsystems of the mechanism of monitoring and control are proposed to include organizational, legal, technological, information-analytical subsystems and the subsystem of decision-making

\section{References}

[1] H. Fayol, Obshchee i promyshlennoe upravlenie [General and Industrial Management], Kontrolling, Moscow, 1992.

[2] Ansoff, Strategicheskoe upravlenie [Strategic Management], Ekonomika, Moscow, 1989.

[3] C. Bowman, Osnovy strategicheskogo menedzhmenta [The Fundamentals of Strategic Management], UNITY, Moscow, 2004.

[4] O.V. Vlasova, Innovatsionnyi menedzhment v APK: uchebnoe posobie [Innovation Management in Agribusiness: Textbook], Saratov State Agricultural University, Saratov, 2013.

[5] V.A. Kardash, E.O. Rapport, Modelirovanie ekonomicheskikh protsessov v selskom khozyaistve [Modeling of Economic Processes in Agriculture], Nauka, Novosibirks, 1979.

[6] R.G. Mumladze, Menedzhment v agropromyshlennom komplekse: Uchebnik [Management in the Agro-Industrial Complex: Tutorial], KNORUS, Moscow, 2013.

[7] I.A. Minakov (ed.), Ekonomika agroprodovolstvennogo rynka: uchebnoe posobie [Economy of the Agro-Food Market: Textbook], INFRA-M, Moscow, 2014.

[8] A.I. Seleznyov, Upravlenie APK. Problemy i puti ikh resheniya. Problemy agropromyshlennogo kompleksa Rossii [The Management of the Agro-Industrial Complex. Problems and Ways of Their Solution. Problems of the Agro-Industrial Complex of Russia], GNU Informagrotekh, Moscow, 2008, pp. 421-422.

[9] P. Drucker, Upravlenie, natselennoe na rezultaty [Managing for Results], Tekhnologicheskaya shkola biznesa, Moscow, 1994. 
[10] I.L. Vorotnikov, Organizatsiya i menedzhment innovatsionnogo agrobiznesa: uchebnoe posobie [The Organization and Management of Innovation Agribusiness: Textbook], Saratovskii istochnik, Nauka, Sarato, 2012.

[11] K.A. Petrov, Upravlenie innovatsionnoi infrastrukturoi agrobiznesa monografiya [Management of innovative Agribusiness Infrastructure: Monography], Saratovskii istochnik, 2013.

[12] M.N. Malysh, V.A. Tkachenko, Agrarnyi rynok: osnovy formirovaniya, razvitiya, regulirovaniya i upravleniya: uchebnoe posobie dlya stud. agrarnykh vuzov po napravleniyam "Ekonomika", "Menedzhment" [Agrarian Market: The Basics of Formation, Development, Regulation and Control: Textbook for Students of Agricultural Universities in the Areas of "Economics", "Management"], Prospekt nauki, St. Petersburg, 2011.

[13] W. King, D. Cleland, Strategicheskoe planirovanie i khozyaistvennaya politika [Strategic Planning and Economic Policy], Moscow, 1982.

[14] G.Kh. Popov, Effektivnoe upravlenie [Effective Management], Ekonomika, Moscow, 1985.

[15] E.A. Khachemizova, Optimizatsiya produktovykh podsistem v APK [Optimization of Product Subsystems in the Agro-Industrial Complex], Ekonomika i sotsium 5(18) (2015).

[16] F.W. Taylor, Printsipy nauchnogo menedzhmenta [The Principles of Scientific Management], Kontrolling, Moscow, 1991. 